\title{
Rare cause of pancolitis
}

\author{
Joana Carmo, ${ }^{1}$ Susana Marques, ${ }^{1}$ Raquel Ilgenfritz, ${ }^{2}$ David Serra $^{3}$
}

${ }^{1}$ Gastroenterology Department, Hospital Egas Moniz, Lisboa, Portugal

${ }^{2}$ Histopathology Department, Hospital da Luz, Lisboa, Portugal

${ }^{3}$ Gastroenterology Department, Hospital da Luz, Lisboa, Portugal

\section{Correspondence to} Dr Joana Carmo, joanavcarmo@gmail.com

Accepted 3 February 2016

\section{DESCRIPTION}

A 63-year-old Caucasian man was admitted to the emergency department due to hematochezia. He also referred mild abdominal pain, constipation and tenesmus intermittently in the past 4 months. He had been submitted to a colonoscopy 1 year before, and it was unremarkable. A new colonoscopy was performed and showed pancolitis with areas of deep ulceration, areas with linear ulcers with cobblestone appearance and multiple pseudopolyps (figure 1). Biopsies were performed, which showed a dense lymphocytic infiltrate with small and medium size cells $\mathrm{D} 20+, \mathrm{CD} 5+, \mathrm{BCL} 2+$ cyclin D1+, CD3- and CD 10-, compatible with a mantle cell lymphoma in colonic mucosa with areas of blastoid variant cells (figure 2). Cervicothoracoabdominopelvic CT showed extensive lymphadenopathy and splenomegaly, and a lymph node biopsy confirmed the diagnosis. The patient was started on chemotherapy and is currently alive, 6 months after diagnosis, despite the poor prognosis.

The patient's age, symptoms and endoscopic appearance were compatible with inflammatory bowel disease (IBD), however, obtaining biopsy specimens was essential to a correct diagnosis. In the differential diagnosis of pancolitis, not only
IBD but infectious and neoplastic conditions should also be considered. Involvement of the colon and rectum by lymphomas is rare $(<1 \%$ of all non-Hodgkin's lymphomas (NHL)). ${ }^{1}$ Mantle cell lymphoma is a rare NHL that affects mainly males in the seventh decade of life. ${ }^{2}$ If the lower gastrointestinal tract is involved, colonoscopy can show ulceration, a single large mass (even in these cases occlusive symptoms are rare), a diffuse lymphomatous polyposis (endoscopically similar to adenomatous polyposis), or a combination of these. $^{23}$

\section{Learning points}

Mantle cell lymphoma is a cause of pancolitis, and its differential diagnosis including IBD can be challenging, mainly if symptoms, patient's age and endoscopic appearance are suggestive.

- Both diseases can present with involvement of the entire colon (pancolitis) with ulceration, diffuse polyposis, a (pseudo) tumoural mass, or a combination of these.

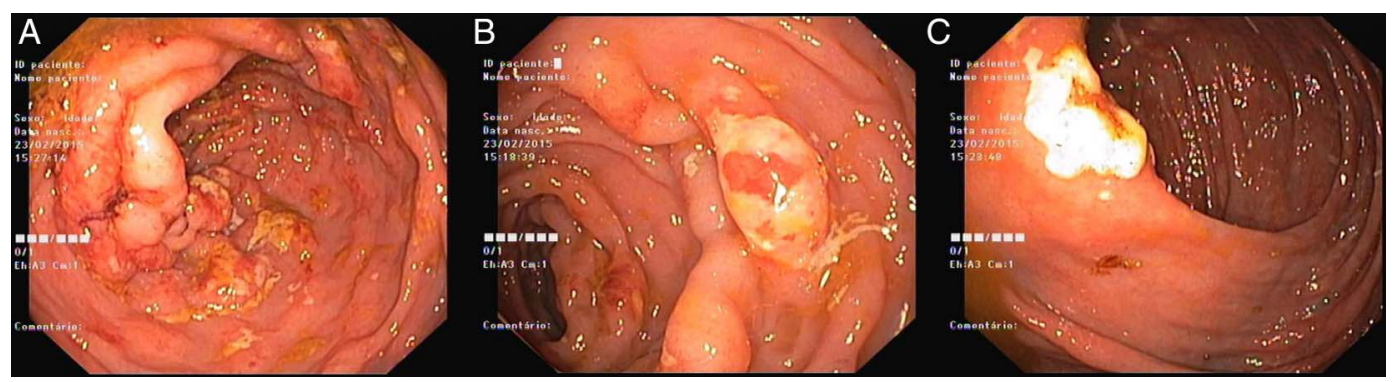

Figure 1 Colonoscopy showing pancolitis with areas of linear ulcers with cobblestone appearance $(A)$, multiple pseudopolyps (B) and deep ulceration of the ileocaecal valve (C).
To cite: Carmo J, Marques $S$, Ilgenfritz $R$, et al. BMJ Case Rep Published online: [please include Day Month Year] doi:10.1136/bcr-2016214468

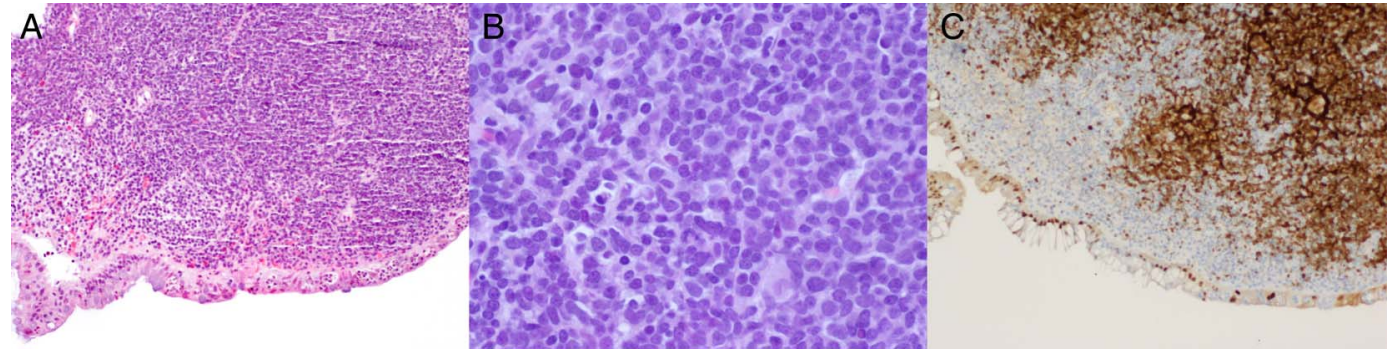

Figure 2 Histology of colonic biopsies showing a dense lymphocytic infiltrate with small-sized and medium-sized cells. (A) H\&E staining, magnification $\times 10$. (B) H\&E staining, magnification $\times 40$. (C) Positive immunohistochemical for cyclin D1, magnification $\times 20$. 
Contributors $J C$ wrote the manuscript. SM and DS were responsible for the revision of its contents. JC and SM followed the patient. DS performed the endoscopic examination. RI performed the histopathological analysis of the colonic biopsies.

Competing interests None declared.

Patient consent Not obtained.

Provenance and peer review Not commissioned; externally peer reviewed.

\section{REFERENCES}

1 Quayle FJ, Lowney JK. Colorectal lymphoma. Clin Colon Rectal Surg 2006; 19:49-53.

2 Vose JM. Mantle cell lymphoma: 2012 update on diagnosis, risk-stratification, and clinical management. Am J Hematol 2012;87:604-9.

3 Stanojevic GZ, Nestorovic MD, Brankovic BR, et al. Primary colorectal lymphoma: an overview. World I Gastrointest Oncol 2011;3:14-18.

Copyright 2016 BMJ Publishing Group. All rights reserved. For permission to reuse any of this content visit http://group.bmj.com/group/rights-licensing/permissions.

BMJ Case Report Fellows may re-use this article for personal use and teaching without any further permission.

Become a Fellow of BMJ Case Reports today and you can:

- Submit as many cases as you like

- Enjoy fast sympathetic peer review and rapid publication of accepted articles

- Access all the published articles

- Re-use any of the published material for personal use and teaching without further permission

For information on Institutional Fellowships contact consortiasales@bmjgroup.com

Visit casereports.bmj.com for more articles like this and to become a Fellow 